\title{
The Right to Cyborgization in Slovenia
}

\author{
BLAŽ IVANC
}

\begin{abstract}
The article deals with the legal aspects of the phenomenon of cyborgization. There is a structured debate about legal and ethical admissibility of the use of scientific and technological interventions in the field of biomedicine, by which we transform or supplement the functioning of the natural human organism in the direction of an increasingly artificial human being. In the discussion, we ask ourselves, to what extent or in what sense it's possible to talk about the right of a person to cyborgization. After discussing the typology of scientific and technological interventions or technologies that can be classified in the field of cyborgization, the discussion draws attention to ethical dilemmas. First, it identifies the distinction between medically indicated interventions, which means cyborgization, and medically unindicated. In the next step, the discussion deals with the distinction between cyborgization interventions, which must be controlled from the point of view of ethics, and other interventions. It tries to define the typology of existing or future unethical and unlawful interventions. Finally, the discussion opens the questions on the way, content and approach to the legal regulation of the phenomenon of cyborgization and attempts to assess the quality of the current legal regulation of that area.
\end{abstract}

Keywords: • Right to Health $\bullet$ Cyborg $\bullet$ Legal Regulation $\bullet$ Personality - Ethics •

CorResPondence AdDress: Blaž Ivanc, PhD, Assistant Professor, Univeristy of Ljubljana, Faculty of Health Sciences, Zdravstvena pot 5, 1000 Ljubljana, Slovenia, e-mail: blaz.ivanc@zf.uni-lj.si. 


\section{Introduction}

A recent debate on the appropriate use of advanced robot technology in connection with artificial intelligence has raised many questions, such as the legal subjectivity of advanced robots (Pagallo, 2018: 1) and the rights of robots (Gunkel, 2018: 596). Although these questions are highly provocative, they are not direct subjects of this debate, which will rather focus its attention on the phenomenon of cyborgization of a human being. The discussion will not explore a highly hypothetical question of a robot's right to become more like a human being, as, per example, in the Asimov's story "The Bicentennial Man". ${ }^{1}$ The main subject of this debate is the question of whether a person has a right to cyborgization and how this supposed right is respected in Slovenia?

We will attempt to answer the various questions surrounding the topic. What phenomenon is called a cyborg? Is the conception of this phenomenon unambiguous, or can there be several meanings? How do we understand the phenomenon of cyborgization in the context of the modern concept of a cyborg? And finally, is (or should be) the cyborgization of a human person the right of an individual? Is there a need, as Barfield and Williams claim, for the creation of a special "law of the cyborg" (Barfield \& Williams, 2017: 15)? Albeit the "Neuro Law" is still not regarded as a new special legal discipline (Gerhard, 2009: 330), perhaps we are challenged by changes in neuroantropology that affect our understanding of the image of a human being in the future?

The question on the existence of an alleged right to cyborgization will be dealt with from the perspective of legal science. The first part of the discussion will try to present the phenomenon of cyborgization and its main characteristics. The right to cyborgization means the individual's right to have legally assured access to, and benefits from those cyborgization interventions that are legally, ethically and socially permissible. The debate will primarily deal with questions regarding the existence of this right in the Slovenian (health) law and in connection with the obligations deriving from European international and supranational law.

Finally, the discussion will present the reasons that support its two main arguments: 1. that the Slovenian law does not have a satisfactory system of control over the use of cyborgization biotechnology in place, and 2. that the right of the individual to the cyborgization interventions is not properly regulated, in particular concerning the patient's satisfactory access to the advanced cyborgization health services.

\footnotetext{
${ }^{1}$ This question is discussed by Blum (2016: 5).
} 


\title{
Cyborgs, Cyborgization and Law
}

\subsection{The Phenomenon of Cyborgization}

In 1960, Clynes and Kline in their widely known article Cyborgy and space used the term "cyborg" (which is an abbreviation for the words "cybernetic organism") in the dissertation on possible technological modifications and alternations of the human body that would enable man's better survival in the space environment. Their definition of the term "cyborg" was narrow and strictly scientific:

\begin{abstract}
$»$ What are some of the devices necessary for creating self-regulating man-machine systems? This selfregulation must function without the benefit of consciousness in order to cooperate with the body's own autonomous homeostatic controls. For the exogenously extended organizational complex functioning as an integrated homeostatic system unconsciously, we propose the term "Cyborg"." (Clynes \& Kline, 1960: 27).
\end{abstract}

They proposed the use of several technological interventions (e.g. the use of an osmotic pressure pump capsule, the removal of the digestive system, the use of sensors that would detect radiation, induced hypothermia, hibernation and the use of pharmaceuticals for various purposes) that would, in a highly invasive manner - affect both the physical and psychological constitution of human beings and thereby solve different psycho-physiological problems that are characteristic for human's existence in the space environment.

Some years later, Lem, in his monograph Summa Technologiae discussed the problem of perfecting the human in a similar way: "Even though the cyborg is capable of running in anaerobic conditions (naturally, with an oxygen supply in its suit), its circulatory system is designed in quite a "traditional" way. The cyborg is not a partly prosthesized human; it is a human that has been reconstructed in part and equipped with an artificial system of nutritional regulation - which facilitates adaptation to various cosmic environments. But such reconstruction has not taken place on a microscopic level; that is, living cells are still the main building material of the cyborg's body. Besides, changes to its organization cannot be carried through to its offspring (they are not hereditary). Presumably cyborgization could be accompanied by the reconstructions of biochemistry" (Lem, 1964, 1997: 342).

Today, in the context of the new technological revolution, Barfield and Williams claim that "cyborg technology" inter alia consists of prosthetic limb replacements and prosthetic hands controlled by thought; neuroprosthetic devices implanted within the brain; and, additionally to people equipped with heart pacers or defibrillators, retinal prosthesis and cochlear implants (Barfield \& Williams, 2017: 1). They define "cyborg prosthesis" more expansively than Clynes, Kline and Lem did by asserting that the term means: "artificial enhancements to the body providing computational capability, which operate as a closed-loop feedback system, are upgradeable, and in some cases controllable by thought and /or implanted directly into the body itself" (Barfield \& Williams, 2017: 2). 
Meanwhile, Lem disfavoured the idea that human's reconstruction via cyborgization should be a project of universal rebuilding of a human being (Lem, 1964, 1997: 342). Kurzweil in his book The Singularity Is Near embraces this idea and presents its radical and utopian development in the light of transhumanistic paradigm. He strongly supports a whole set of cyborgization interventions, including, inter alia, a radical upgrading of human bodies' physical and mental systems using biotechnology and emerging genetic-engineering technologies; the use of nanobots to augment and ultimately replace human organ;, a redesign of the digestive system; the disentanglement of sex from its biological function; the use of artificial and programmable blood; a full-scale replacement of a human heart (by microscopic fuel cells) and other human organs; and, a redesign of the human brain. These interventions, should they prove true, will mean that by the 2030's human beings will become more nonbiological than biological entities, and the process of transformation of a human race would result in the creation of a universal "Human Body Version 3.0" having mostly nonbiological brains and the ability to change itself (Kurzweil, 2005: 228-234). The idea of a superhuman is supported by Moravec, who claims that when intelligent robots will carry out human cultural evolution - without humans and genes that build human beings -, including their own construction and increasingly rapid self-improvement, human's "DNA will find itself out of a job, having lost the evolutionary race to a new kind of competition" (Moravec, 1988: 2). Barfield maintains that some publicly known cyborgs (e.g. Steve Mann and Neil Harbisson) are already "gradually working their way into our lives and leading humanity toward the Singularity" (2016: 50).

Tegmark, who defines cyborg as a human-machine hybrid, observed that Moravec and Kurzwell's common understanding of cyborgization interventions goes "far beyond merely improving our DNA" and into the direction of "eliminating human body entirely and uploading minds, creating a whole-brain emulation in software...". (Tegmark, 2017: 39). The transhumanist agenda of cyborgization seems not only to be fully engaged in the experiment de hominis natura, but also tries to subvert and radically change the nature of a human being.

Lepora, on the other hand, departs from the "cyborg" terminology and instead speaks in terms of "biohybrid systems", for example: brain-machine interfaces, micro - and nano-biohybrids, and biohybrid robots designed using synthetic biology tools, prosthetic hands with a sense of touch, cochlear replacements that restore hearing, and brain implants that can boost cognitive functions (Lepora, 2018: 459).

We can conclude from what we have discussed above that an important shift in the concept of the term "cyborg" has occurred; from a narrow scientific concept to a much broader, but also more elusive concept, which can - concerning the human body - vary from non-invasive to extremely invasive interventions. Leaving aside a vast, influential and highly suggestive scenery of "cyborg" imagination in science fiction literature and in the film industry, we will try to focus on the scientific use of modern biotechnology as seen from the legal perspective. 
When asking ourselves to what extent or in what sense it is possible to talk about the right of a person to cyborgization, we will accept some limitations. By a person we mean only the human being. Thus, under the term cyborgization, we will exclude the interweaving of non-human organisms and machines, and focus instead on the interconnection between the human organism with a "machine" or biotechnological devices. Because of this self-imposed limitation, this paper will not address questions about cyborgization of non-human organisms, a topic that certainly is worthy of exploration in its own right.

\subsection{Cyborgization Interventions and their Dichotomies}

For the purposes of this discussion, we will assume that cyborgization interventions mean any interventions that, with the use biotechnology (e.g. manipulation, prosthetization, enhancement or redesign of a human being, including inter alia genetic manipulation of human DNA and cloning), lead to the creation of a human and machine merger. Because there is no unambiguous or widely accepted definition of a cyborg and of cyborgization process or interventions, it is very hard to discuss the typology of cyborgization interventions in a comprehensive way. However, it is possible to differentiate between some main characteristics of such interventions and dichotomies accompanying them.

\subsubsection{Medically and Non-medically Indicated Cyborgization Interventions}

First, we can differentiate between cyborgization interventions that are medically indicated and others that fail to have a medical indication. Quigley and Ayihongbe are in favour of a wider conceptualization of cyborgization interventions that are mainly medically indicated and typical for »everyday cyborgs « that are »(i) persons with 'technologies of the carpentry kind' such as artificial joints, as well as simple prosthetics such as aesthetic arm prostheses and cosmetic ocular prosthetics (artificial eye); (ii) those carrying devices, such as insulin pumps, which are automated to monitor blood glucose and deliver insulin; (iii) persons with implanted medical devices such as pacemakers, ICDs, cochlear implants, or deep brain neurostimulators, which regulate or replace some physiological function or other; and (iv) persons with complex prosthetics such as retinal prostheses ('the bionic eye') or myoelectric prosthetic arms« (Quigley \& Ayihongbe, 2018: 279).

As a rule, medically indicated cyborgization interventions on a human being are of a limited extent, because of their basic purpose (telos), which is to replace a missing body part and/or to (completely or at least partially) restore normal functioning of a human body, whereby - in some cases - they may even enhance its normal functionality. Evidently, due to the constant innovation and progressive development in fields of medicine, technology and life sciences, we cannot make a final list of cyborgization technologies (such as prosthesis, various kind of implants or other devices). 
As shown by Quigley and Ayihongbe (2018: 277), medically indicated cyborgization interventions and regulations already affect different areas of law, e.g. the law on medical devices, the regulations on their safety, and product liability in cases they cause a damage; the legal liability for damages to devices; the laws that provide for the protection of personal data and of individual's privacy, the regulation that provides for security od medical devices and aims to prevent biohacking; and the legal protection of intellectual property rights. They rightly argue that this "bounded object" regulatory approach somehow overlooks the subjective dimension, which should be more focused on persons with implants or using the cybernetic devices in some other way (Quigley \& Ayihongbe, 2018: 280). Thus, we will try to focus on the subjective dimension of cyborgization interventions, whereby focusing on the issue of individual's right(s).

In the case of medically indicated cyborgization interventions, the right to cyborgization clearly falls within the scope of the right to healthcare and, eventually, also within the scope of rights of disabled people. In Slovenian constitutional law, the right to healthcare (Const. art. 51), the right to social security (including mandatory health insurance) (Const. art. 50) and rights of the disabled (Const. art. 52) represent a necessary normative basis for interpreting the content of the right to cyborgization in medically indicated cases, whereas equitable access to health care services must be assured in all basic aspects, reaching from physical, geographical, temporal, qualitative, ethical, cultural, economic to informational accessibility (Ivanc, 2011: $835)$.

\subsubsection{Non-medically Indicated Cyborgization Interventions}

The telos that moved Clynes and Kline to use the term "cyborg" and to propose the above-mentioned cyborgization interventions was quite contrary to the medically conditioned telos that aims to help the patient. They proposed to use various medical techniques, but for the sole scientific purpose of adapting the human body to conditions of living in the space environment (Clynes \& Kline, 1960: 27). In general, the telos of non-medically indicated cyborgization interventions does not rest with a medical reason that calls for - and thereby, in principle, ethically justifies - a medical intervention into the human body and mind. Thus, such interventions are ethically harder to justify. In addition, they tend, in principle, to be more invasive in nature, and of a wider- or even full-scale range. From the legal perspective, the most problematic cyborgization interventions are those which telos sides with the idea of a universal rebuilding of a human being. Per example, (universal) cyborg soldiers are created solely for military usage. ${ }^{2}$ In Brenner's opinion, it is the military that will be the driving force in the emergence of enhanced humans (Brenner, 2013: 71). Greguric observes that cyborgization also has given rise to many new dilemmas in the area of sport competition. They are not only connected with athlete's wearing special prosthesis (e.g. the athlete Oscar Pistorius), but also with other modifications of sportsman's bodies (Greguric, 2012: 102).

\footnotetext{
${ }^{2}$ For example, in the science fiction film »Universal Soldier« (1992, Emmerich, R. dir., Shapiro, A., Baumgarten C., \& Joel, B., prod.) A similar example is a known film figure man-machine hybrid policeman »RoboCop« (1987, Verhoeven, P. dir., \& Neumeier, E., \& Miner, M.) with a law-enforcement purpose.
} 
Interestingly, Wiener in his book The Human Use of Human Beings - Cybernetics and Society (that is a popularization of his previous book Cybernetics) refers to a critique of his former book (1989: 178), published by Dominican friar Dubarle, who warned against the phenomenon of machine à gouverner, namely the potential risks that an artificial machine (this is in today's terms the artificial intelligence - AI) could take over all governance of world matters (Dubarle, 1948). In Wiener's opinion, the real danger presented in the use of such machines lies in their being used "by a human being or a block of human beings to increase their control over the rest of the human race or that political leaders may attempt to control their populations by means not of machines themselves but through political techniques as narrow and in different to human possibility as if they had, in fact, been conceived mechanically" (Wiener, 1989: 181). Consequently, we are faced with a challenge of a humane use of modern biotechnology that will endure to the general benefit, and not to the detriment, of all human race.

\subsubsection{Legal and Illegal Cyborgization Interventions}

Despite a great popularity of the "blurring the boundaries between a human and the machine" argument (Van Est, \& Gerritsen, \& Kool, 2017: 15), we need to stress that the law's basic mission somehow runs in the opposite direction: the law not only strives to set the limits (or boundaries) of human actions, but also tries to maintain and prolong them, if necessary by imposing various sanctions. Although the use of some technologies is possible, the law bans or may prohibit their use, because they may interfere with some legally protected interests, e. g. with the human right to physical and mental integrity and/or privacy. Thus, the issue of boundaries seems to be the "ultimate" question or domain of the law. From the perspective of the law's mission of setting boundaries, we may discuss another dichotomy or a difference between legal and illegal cyborgization interventions, in the context of Slovene law in connection with the Council of Europe's law and European Union's law.

A general quest for the protection of human rights, including the guarantees to protect the individual's life, personal liberty, security, privacy and family life; and through prohibiting torture, slavery and forced labour, has been enshrined in the provisions of the European Convention for the Protection of Human Rights and Fundamental Freedoms (Council of Europe, 1950; hereinafter: the ECHR). Subsequently, attempts to help guarantee the humane use of biotechnology has been enshrined into the Convention for the Protection of Human Rights and Dignity of the Human Being with regard to the Application of Biology and Medicine: Convention on Human Rights and Biomedicine (as amended with Protocols) (Council of Europe, 1997; hereinafter: the Oviedo Convention). The Republic of Slovenia signed and ratified the Oviedo Convention and its Protocols. Thus, the Slovene law must follow its main purpose and objective, which is to "protect the dignity and identity of all human beings and guarantee everyone, without discrimination, respect for their integrity and other rights and fundamental freedoms with regard to the application of biology and medicine « (Oviedo Convention, art. 1). 
One of the leading general principles of the Oviedo Convention is the primacy of the human being, which in turn rests on the concept of human dignity (Oviedo Convention, art. 2). The primacy of the human being is also one of the general principles of the Universal Declaration on Bioethics and Human Rights (UNESCO, 2005, 2006, art. 3). The first paragraph of article 1 of the Oviedo Convention deals with a situation of conflicting interests or purposes: on the one side we have the telos of legal protection of the interests and welfare of the human being, while on the other side is the issue of how best to ensure or protect the equally important matter of the scientific development and/or the interests of the society.

The fundamental value claim of this provision is to give precedence to the legal protection of a human being as a central subject of law (this is to his/her dignity, interests and welfare). The provision therefore prohibits an objectification of a human person in a manner that would degrade a person into an arbitrarily disposable object of scientific exploration and experimentation on the one hand, and/or of different arbitrary interests of the society on the other hand (Oviedo Convention, para. 1, art. 2 ). Thus, the use of human enhancement (cyborgization) techniques of genetic manipulation of the human DNA and of cloning is not allowed. Also prohibited is any (other) scientific research that interferes with the primacy of a human being (Oviedo Convention, para. 2, art. 2).

As far as Member States of the European Union are concerned, this concept of the protection of the human being's fundamental dignity is observed also by the Charter of Fundamental Rights of the European Union (hereinafter: the CFR), which in article 3 ensures the right to the integrity of the human person, and reads as follows:
"1. Everyone has the right to respect for his or her physical and mental integrity.
2. In the fields of medicine and biology, the following must be respected in particular:
- the free and informed consent of the person concerned, according to the procedures laid down by law,
- the prohibition of eugenic practices, in particular those aiming at the selection of persons,
- the prohibition on making the human body and its parts as such a source of financial gain,
-the prohibition of the reproductive cloning of human beings."

Conclusively, we can state that, in Europe, some kinds of cyborgization intervention are directly (e. g. cloning, eugenic practices) or indirectly prohibited. In principle, all scientific research (which ultimately might lead to a wide spread of a certain technology) must be ethically reviewed. A production of human clones, such as described by Huxley in the Brave New World (Huxley, 1998), cannot be legally justified under the provisions of the Oviedo Convention and the CFR. Under the legal prohibition of the above-mentioned international treaties, any kind of creation of enhanced humans ("superhumans" or "humans+"), such as cyborg soldiers or other cyborg law-enforcement agents, that would lead to eugenic practices or creation of human subspecies, also are strictly prohibited. 
Another new challenge is posed by the introduction of new robotic technologies. Van Est, Gerritsen, and Kool claim that - in respect to the present use of robot technology - we already face a "serious erosion of human rights" (Van Est, Gerritsen, and Kool, 2017 , p. 46). Thus, they propose not only the introduction of two new (defensive) rights: the right not to be measured, analysed or coached, and the right to meaningful human contact, but call for the adoption of a convention on human rights in the robot age (Van Est, Gerritsen \& Kool, 2017: 43). The Report on Robotics Ethics of the World Commission on the Ethics of Scientific Knowledge and Technology supports this idea in order to deal with the asymmetrical effects of the introduction of robotic technologies. New regulatory dilemmas and proposals are closely linked with ethical challenges (COMEST, 2017: 39).

\subsubsection{Ethically Admissible and Non-admissible Cyborgization Interventions}

The third dichotomy is related to the question of the ethical admissibility of the use of scientific and technological interventions (or technology) on human beings in the field of biomedicine, by which - with the help of artificial parts or technologies - we transform or supplement the functioning of the natural human organism.

In general, scientific research in the fields of biology and medicine may be carried out freely, subject to the provisions of the Oviedo Convention and the other legal provisions ensuring the protection of the human being (Oviedo Convention, art. 15). Article 16 of the Oviedo Convention enshrines special requirements for the protection of persons undergoing research, such us: absence of alternative methods of research on humans, proportionality of risk and the potential benefits of the research, informed (and withdrawable) consent for involved persons with appropriate safeguards for their protection, whereas the point iii of the provision explicitly requires that each research project "has to be approved by the competent body after independent examination of its scientific merit, including assessment of the importance of the aim of the research, and multidisciplinary review of its ethical acceptability". Clearly, the contracting parties to the Oviedo Convention must provide for a regulated and well-operational system of ethical review of all research in the field of biomedicine.

In order to assure the proper ethical review of the use of modern biotechnology, a twofold approach is followed in the international legal instruments. First, relevant legal instruments provide for a spectrum of principles and values (e.g. human dignity, primacy of a human being, principles of equality and non-discrimination, justice, solidarity). Second, legal instruments call for the creation of a system (and a special body) that would conduct ethical reviews of the use of modern technology. The international law may prohibit the use of some kinds of cyborgization interventions and instruments to evaluate the other. However, the greater challenge is to introduce and regulate a system of effective ethical review of the use of modern biotechnology on the level of member states (Fukuyama, 2002: 204). Thus, we will turn our attention to Slovenian law that is relevant for cyborgization interventions. 


\subsection{Legal Regulation of Cyborgization in Slovenia}

The Slovenian legal framework that is relevant for regulation of cyborgization interventions is complex and heterogenous, since it is composed of normative provisions coming from the constitutional law, from the international law and from different areas of statutory law, including, per example, the criminal law, the health law, and the law on scientific research. The Article 8 of the Constitution of the Republic of Slovenia (hereinafter: the Constitution) provides that laws and other regulations must comply with generally accepted principles of international law and with treaties that are binding on Slovenia, whereas ratified and published treaties are directly applicable. ${ }^{3}$ The Slovenian legislator tried to satisfy the legal obligations arising from the Oviedo convention (and its Protocols), and from the CFR, by the supplementation of existing statutes, e.g. the Health Services Act (hereinafter: the ZZDej) ${ }^{4}$, or by creation of new statutes, such as, per example, the Patients' Rights Act (hereinafter: the ZPacP) ${ }^{5}$, the Mental Health Act (hereinafter: the ZDZdr) ${ }^{6}$, and the Criminal Code of the Republic of Slovenia (hereinafter: the KZ-1) ${ }^{7}$, which were enacted in 2008.

The introduction of the ZPacP and the ZDZdr in 2008 provided for guarantees related to the assurance of patients' informed consent, protection of patients' right to privacy and other rights, by stressing the importance of patients' human dignity, autonomy, integrity and security (see art. 3 of the ZPacP). According to the obligations arising from the Oviedo convention and its Protocols, and the CRF, the use of certain biotechnological procedures and techniques that also mean cyborgization interventions (e.g. cloning of a human being, creation of chimeras) are subject to incrimination. Chapter fourteen, article 114 on the criminal offences against humanity of the KZ-1 prohibits the creation of living beings, including, for example, cloning of human being, creation of chimeras, use of genetic research prohibited by international law, acts that endanger the integrity or life of a human embryo during research on human embryos. ${ }^{8}$

\footnotetext{
${ }^{3}$ Ustava Republike Slovenije — URS (Uradni list RS, št. 33/91-I, 42/97 - UZS68, 66/00 - UZ80, 24/03 UZ3a, 47, 68, 69/04 - UZ14, 69/04 - UZ43, 69/04 - UZ50, 68/06 - UZ121,140,143, 47/13 - UZ148, 47/13 - UZ90,97,99 and 75/16 - UZ70a).

${ }^{4}$ Zakon o zdravstveni dejavnosti - ZZDej (Uradni list RS, št. 23/05 -oficially consolidated text, 15/08 ZPacP, 23/08, 58/08 - ZZdrS-E, 77/08 - ZDZdr, 40/12 - ZUJF, 14/13, 88/16 - ZdZPZD, 64/17 in 1/19 odl. US).

${ }^{5}$ Zakon o pacientovih pravicah - ZPacP (Uradni list RS, št. 15/08 and 55/17).

${ }^{6}$ Zakon o duševnem zdravju - ZDZdr (Uradni list RS, št. 77/08 and 46/15 - odl. US).

${ }^{7}$ Kazenski zakonik - KZ1 (Uradni list RS, št. 50/12 - uradno prečiščeno besedilo, 6/16 - popr., 54/15, $38 / 16$ in 27/17).

${ }^{8}$ Article $114 \mathrm{KZ}-1$ reads as follows:

"(1) Whoever manufactures or participates in manufacturing or attempts to manufacture or crossbreed human beings or other species, which is harmful for the humankind and banned according to the regulations and international law, shall be sentenced to imprisonment between five and fifteen years.

(2) If the act referred to in the preceding paragraph concerns creation of a human being, who is genetically identical with another living or dead human being, creation of human embryos for research, industrial or commercial purposes, or exchange of important human body parts or organs, which is banned according to the regulations and international law, the perpetrator shall be sentenced to imprisonment between ten and fifteen years.

(3) Whoever performs genetic research, which could forecast hereditary diseases or enable determination of carrying the gene responsible for the disease, or identify genetic predisposition or susceptibility to a
} 
Other cyborgization (research) interventions in the field of biomedicine are subject to mandatory ethical review, conducted by the National Medical Ethics Committee (hereinafter: the NMEC). The legal duty of each scientific research endeavour in the field of biomedicine to undergo a mandatory ethical review is enshrined in the article 60 of the ZZDej. Article 60 of the ZZDej is deficient, however, because it leaves many important questions unresolved, e. g.: the full institutional, financial and organizational independence of the NMEC; the process of appointment and of dismissal of the members of the NMEC; their mandate, status and responsibilities; the (survey) powers of the NMEC in relation to the powers of other bodies that conduct ethical review; and, the decision-making process and due process rights of persons that submit their petition for a review. There is a clear and pressing need for the legislator to enact a new statute that would comprehensively regulate all issues that relate to the scientific research and ethical review. In this way, the question of the appropriate ethical review of non-medically indicated use of modern biotechnology may be properly addressed as well. In addition, the legislator still did not enact statutory provisions that would transpose the provisions of two Additional Protocols to the Oviedo Convention, concerning biomedical research and genetic testing for health purposes, into the Slovenian domestic law.

In addition, a two-tier regulatory approach should be of a major concern for lawyers. While at the same time enumerating legal principles and values (legal and ethical principalism) in "hard" legal documents, the regulation may also proceed on a quite different and separate track of creating purely technical standardisation rules on new ethically questionable (cyborgization) biotechnology, which remains below the "radar" not only of legal experts, but also of a decision-making political process in a democratic society.

Regarding the application of cyborgization techniques that might be under development in other scientific areas than of biomedicine, the legal regulation of scientific research seems to be of additional concern. The Research and Development Activity Act (hereinafter: the ZRRD) ${ }^{9}$ calls for ethical and responsible scientific research (art. 2) but has no system of ethical review of scientific research activities. The legislator is trying to deal with this deficiency by enacting the draft Scientific Research Act that would in the art. 13 set up the National Council for integrity in science. ${ }^{10}$ However, the legal position and competences of the National Council for integrity in science is even weaker than that of the NMEC. Consequently, the system

\footnotetext{
disease, but the research is not performed exclusively for medical purposes or as medical research for medical purposes, or whoever in conducting research abandons appropriate genetic consultancy or, by violating regulations, conducts research in the field of biology and medicine, which are banned according to the regulations and international law, shall be punished with a fine or sentence of imprisonment of not more than three years.

(4) Whoever endangers the integrity or life of a human embryo during research on human embryos shall be punished in the same manner as in the preceding paragraph.

(5) Whoever enables act under paragraphs 1 or 2 of this Article by providing financing, buildings, devices or material to create living beings or to crossbreed them, by recruiting co-workers, or different organisation of the creation shall be sentenced to imprisonment between three and ten years."

${ }^{9}$ Zakon o raziskovalni in razvojni dejavnosti - ZRRD (Uradni list RS, št. 22/06 - uradno prečiščeno besedilo, 61/06 - ZDru-1, 112/07, 9/11, 57/12 - ZPOP-1A, 21/18 - ZNOrg and 9/19).

${ }^{10}$ Predlog Zakona o znanstveno-raziskovani dejavnosti. Retrived from: https:/e-uprava.gov.si/drzava-indruzba/e-demokracija/predlogi-predpisov/predlog-predpisa.html?id=8644 (March 20, 2019).
} 
of ethical review of the cyborgization biotechnology in Slovenia has serious deficiencies.

In the case of medically indicated cyborgization interventions, the Slovenian health law contains some provisions that make access to - at least some - such health services or devices difficult. We will discuss two cases, first a hypothetical case and then a real case, in which a patient need for a cyborg medical device was involved.

First, if a patient in Slovenia requests a bionic prosthetic arm that would replace a missing arm, he or she will face a similar legal situation as a patient from the Netherlands (Sentges v. The Netherlands, 2003), who unsuccessfully brought the case to the European Court for Human Rights (hereinafter: the ECHR). The Court relied on the margin of appreciation doctrine and held that, although a robotic arm as a highly expensive medical device was not among listed medical devices in a Member State, it was still within the State's margin of appreciation to determine the scope of the health insurance entitlement (den Exter, 2017: 192). Similarly, the Slovenian Health Care and Health Insurance Act ${ }^{11}$ (hereinafter: the ZZVZZ) deficiently and in a nontransparent way regulates the right to receive medical devices, such as bionic prosthesis, use of exoskeleton, advanced cochlear hearing aids (ZZVZZ, 1992, arts. 23, 61, 63a, 202).

In September 2018, a surgical team employed at the University Medical Centre of Ljubljana performed a demanding surgical operation on a 5-year old Italian patient, in which they successfully positioned an Acoustic Brainstem Implant (ABI) into the patient's brainstem. This kind of operation and the costs for the ABI are not covered by the mandatory health insurance in Slovenia, because the ABI device is not on the list of medical devices of the mandatory health insurance (Zupanič, 2018). Thus, we can state that the Slovenian legislation fails to observe the rights of the disabled as provided by the UN Convention on the Rights of Persons with Disabilities and its Optional Protocol, especially the provisions guaranteeing personal mobility (art. 20), access to healthcare (art. 25), and (re)habilitation (art. 26) (United Nations, 2006).

Finally, we may conclude that the Slovenian health law as currently written does not provide Slovenian patients with equitable access to the technologically advanced cyborgization intervention and devices in the described cases that are medically indicated and ethically acceptable.

In this paper we were unable to explore the question of robot's rights. We would simply observe that there is an ongoing debate relating to this issue with some authors arguing against acknowledging rights to robots (Bryson, 2010: 63; Solaiman, 2017: 37 ) or for their extended legal personhood (Glenn, 2018: 240). Differently than in the case of robots, the question of having rights and duties is not relevant for cyborgs, since they $a b$ initio are humans.

\footnotetext{
${ }^{11}$ Zakon o zdravstvenem varstvu in zdravstvenem zavarovanju - ZZVZZ (Uradni list RS, št. 72/06 - uradno prečiščeno besedilo, 114/06 - ZUTPG, 91/07, 76/08, 62/10 - ZUPJS, 87/11, 40/12 - ZUJF, 21/13 - ZUTDA, 91/13, 99/13 - ZUPJS-C, 99/13 - ZSVarPre-C, 111/13 - ZMEPIZ-1, 95/14 - ZUJF-C, 47/15 - ZZSDT, 61/17 - ZUPŠ in 64/17 - ZZDej-K).
} 
Perhaps the deepest dichotomy concerning cyborgization is of a philosophical, ethical, anthropological, (to some extent) theological and cultural nature. The right of a human being to cyborgization appears to be highly ambiguous and restricted, basically depending on the telos, scope, invasiveness and proportionality of the cyborgization intervention.

\section{Conclusion}

The discussion has shown that the Slovenian law only partially regulates some cyborgization interventions by imposing some prohibitions or by raising a general claim for ethical review of their use in the scientific research, but without a well thought-out and legally regulated system for ethical review of the cyborgization biotechnology. As far as the individual's right to have access to cyborgization interventions and technologies is concerned, the discussion revealed that patient's access to advanced cyborgization health services is poorly regulated and cannot be regarded as providing equitable health care.

There is no compelling need for legal scholars to rush in various cyber legal constructions of legal personalities for machines. However, the use of modern biotechnology urgently demands a more comprehensive approach by national lawmakers and even global legal regulation. While the law does not have to concern itself with purely speculative and utopian ideas, it must concern itself with the possible (mis)use of modern technology, if that technology has the potential to endanger human rights and freedoms, human dignity, basic values and goods of our society. This is the reason e.g. for the need for the legal regulation of genetic technology in the fields of biomedicine, engineering and various other cyborgization interventions which the law must take care to assess.

The Slovenian legislator should put in place a system of comprehensive ethical and legal review of (cyborgization) biotechnologies that would: 1. provide for a stronger position of the NMEC (or even more desirable establish a new agency), 2. enact the bill regulating scientific research that would create an ethics council with appropriate mandate, structure, financing and powers, 3. fully transpose two Additional Protocols to the Oviedo Convention concerning biomedical research and genetic testing for health purposes, and 4. supplement the ZZVZZ with the intention to provide better patient's access to advanced cyborgization health services, such as, per example, bionic prosthesis, exoskeletons, and advanced cochlear hearing aids.

On the one hand, some aspects of cyborgization interventions may be ethically and legally favourable (e.g. the use of advanced prosthetic limbs is a part of the already existing right to healthcare, acceptable or at least socially tolerable). On the other hand, other kinds of cyborgization interventions or practices that are already prohibited by law, such as practices that violate the physical and mental integrity of a human person; the reproductive cloning of human beings; practices that make the human body and its parts as such a source of financial gain; practices that violate the free and informed consent of the person concerned; the creation of chimeras; and, interventions that mean eugenic practices, in particular those aiming at the selection of persons (e. g. creation of enhanced humans). In such cases, it is not justifiable to 
speak about the individual's right to cyborgization, but - on the contrary - about the individual's duty not to engage in such activities.

It seems that a special or per se right of the individual to cyborgization does not exist and should not be acknowledged in the future. Due to the protection of human dignity and integrity no legal duty of cyborgization of a human person may ever exist. A freedom to undergo cyborgization intervention cannot be without strict limitations and prior ethical review. If the cyborgization of a human person will progress anyway, it must be accompanied by a human right of decyborgization.

A legal scholar is not well-positioned to provide an answer to the question of whether living and animated machines may be artificially created by man from a nonbiological material with the use of modern biotechnology. However, the legal science has a fundamental obligation to - at least - pose questions on the use of modern biotechnology that could undermine the fundamental mission of law, which is to protect the dignity of a human person. The concept of dignity of a human person that is enshrined in the modern Human Rights Law represents the basic framework for assessing the acceptability of modern biotechnological interventions, including those that lead to various kinds of cyborgization of a human being.

It the future debate about new sets of rights - induced by the new use of biotechnology - we may not only consider the right not to be measured, analysed or coached, and the right to meaningful human contact, but also the right not be cyborgized and the right to be de-cyborgized. The right to cyborgization may only, by its nature, be accessorial and acknowledged in relation to medically indicated cases, if they - having only a limited focus (e.g. bionic limbs, implantation of the ABI or an artificial eye) approve to be ethically acceptable.

We surely will have in our possession novel technologies that would enable us to proceed further with such cyborgization interventions, which would be contrary to the dignity and primacy of a human being, and would have the potential to endanger or violate human rights. However, it is within our moral power to set (also by law) the boundaries between those usages of technologies that are beneficial and those that are pernicious for human beings, for our existence, culture and civilization.

\section{Legislation, cases}

Council of Europe, (1950) European Convention for the Protection of Human Rights and Fundamental Freedoms, (as amended by Protocols Nos. 11 and 14, 4 November 1950). ETS No. 5. 5 Retrieved from: https://www.echr.coe.int/Documents/Convention_ENG.pdf(February 3, 2019)

Council of Europe, (1997) Convention for the Protection of Human Rights and Dignity of the Human Being with regard to the Application of Biology and Medicine: Convention on Human Rights and Biomedicine (as amended with Protocols). ETS No. 164, Oviedo, 04/04/1997. Retrieved from: https://rm.coe.int/168007cf98 (February 3, 2019)

European Court of Human Rights, (2004/2) Case of Sentges v. The Netherlands, 8 July 2003, no.27677/02 (second section). 
European Parliament (2017) European Parliament resolution of 16 February 2017 with recommendations to the Commission on Civil Law Rules on Robotics (2015/2103(INL)). Retrieved from: http://www.europarl.europa.eu/sides/getDoc.do?pubRef=-//EP//TEXT+TA+P8-TA2017-0051+0+DOC+XML+V0//EN\#top (December 10, 2018)

European Union, (2012) Charter of Fundamental Rights of the European Union, OJ C 326, 26.10.2012, pp. 391-407.

UNESCO (2005) Explanatory memorandum on the elaboration of the preliminary draft Declaration on Universal Norms on Bioethics. Paris: UNESCO - Intergovernmental Meeting of Experts Aimed at Finalizing a Draft Declaration on Universal Norms on Bioethics, 1st, Paris, 2005. Retrieved form: https://unesdoc.unesco.org/ark:/48223/pf0000139024 (February 21,2019)

UNESCO (2006) Universal Declaration on Bioethics and Human Rights. Retrieved from: https://unesdoc.unesco.org/ark:/48223/pf0000146180 (February 21, 2019)

UNITED NATIONS (2006) The Convention on the Rights of Persons with Disabilities and its Optional Protocol (A/RES/61/106) adopted on 13 December 2006.

\section{References}

Barfield, W. (2016) Cyber Humans: Our Future with Machines (New York, NY: SpringerVerlag).

Barfield, W. \& Williams, A. (2017) Law, Cyborgs, and Technologically Enhanced Brains, Philosophies, 2(6), pp. 1-17, doi: 10.3390/philosophies2010006.

Blum, P. R. (2016) Robots, Slaves, and the Paradox of the Human Condition in Isaac Asimov's Robot Stories, Roznicki Kulturoznawcze, VII/3, pp. 5-24, doi: http://dx.doi.org/10.18290/rkult.2016.7.3-1.

Brenner, S. W. (2013) Humans and Humans+: Technological Enhancement and Criminal Responsibility, Boston University journal of Science and Technology Law, Vol. 19, retrieved from: https://ssrn.com/abstract=2360756 (February 1, 2019)

Bryson, J. J. (2010) Robots should be slaves, In: Y. Wilks (Ed.) Close engagements with artificial companions: key social, psychological, ethical and design issues (Natural Language Processing; Vol. 8) (Amsterdam: John Benjamins Publishing Company), pp. 63-74.

Clynes E. M. \& Kline., S. N. (1960) Cyborgs and Space, Astronautics, (14), pp. 26-27, 74-76, September.

COMEST (World Commission on the Ethics of Scientific Knowledge and Technology of UNESCO). (2017). Report of COMEST on robotics ethics, retrieved from: https://unesdoc.unesco.org/ark:/48223/pf0000253952 (January 2, 2019).

Glenn, L. M. D. (2018) What is a Person?, In: Bess, M. \& Pasulka, D. W. (eds.) Posthumanism: the Future of Homo Sapiens (Farmington Hills, Mich. : Macmillan Reference USA, a part of Gale, a Cengage Company), pp. 229-246, retrieved from: https://www.researchgate.net/profile/Linda_Glenn/publication/327802372_What_Is_a Person/links/5ba550efa6fdccd3cb69db05/What-Is-a-Person.pdf (February 1, 2019)

Gruber, M.-C., (2009) Neuro-Theorien des Rechts, In: Buckel, S., Christensen, R., \& FischerLescano, A. (eds.) Neue Theorien des Rechts, 2nd Edition (Stuttgart: Lucius \& Lucius, UTB).

Huxley, A. (1998) Brave New World (First Perennial Classics ed.) (New York: Harper Collins Publishers).

Ivanc, B. (2011) Pravica do zdravstvenega varstva - 51. člen, In: Avbelj, M, et al, Šturm L. (ed.) Komentar Ustave Republike Slovenije, Dopolnitev - A (Kranj : Fakulteta za državne in evropske študije), pp. 816-873. 
Dubarle, D. (1948) Une nouvelle science : la cybernétique - Vers la machine à gouverner ?, Le Monde, 28 décembre 1948, retrieved from: https://sniadecki.wordpress.com/2013/03/08/dubarle-machine/ (January 2, 2019).

den Exter, A. (2017) The Right to Healthcare Under European Law, Diametros, 51, pp. 173 195, doi: 10.13153/diam.51.2017.1037.

Fukuyama, F. (2002) Our Posthuman Future: Consequences of the Biotechnology Revolution (New York: Farrar, Strauss and Giroux).

Greguric, I. (2012) Kiborgiztacija u sportu - stvaranje tijela bez granica u doba transhumanizma. Metodički ogledi, 19(1), pp. 95-111.

Gunkel, D. J. (2018) Can machines have rights?, In: Prescott, T. J., Lepora, N. F., \& Verschure, P. F. M. J., (eds) Living Machines - A Handbook of Research in Biomimetic and Biohybrid Systems (Oxford: Oxford University Press), pp. 596-601.

Jonas, H. (1997) Das Prinzip Leben: Ansätze zu einer philosophischen Biologie (Frankfurt am Main, Leipzig: Insel Verlag, Suhrkamp Taschenbuch Verlag).

Kurzweil, R. (2005) The Singularity Is Near (New York: Viking Adult).

Leenes, R., \& Lucivero, F. (2014) Laws on Robots, Laws by Robots, Laws in Robots: Regulating Robot Behaviour by Design, Law, Innovation and Technology, 6(2), pp. 193-220, doi: https://doi.org/10.5235/17579961.6.2.193.

Lem S. (1964, 2013) Summa Technologiae, transl. Joanna Zylinska (Electronic mediations series) (Minneapolis: University of Minnesota Press), retrieved from: https://publicityreform.github.io/findbyimage/readings/lem.pdf (February 1, 2019).

Pagallo, U. (2013) The laws of robots: Crimes, contracts, and torts (Dordrecht: SpringerVerlag).

Pagallo, U. (2018) Vital, Sophia, and Co.-The Quest for the Legal Personhood of Robots, Information, 9(230), pp. 1-11, doi: https://doi.org/10.3390/info9090230.

Prescott, T. J., Lepora, N. F., \& Verschure, P. F. M. J. (eds) (2018) Living Machines - A Handbook of Research in Biomimetic and Biohybrid Systems (Oxford: Oxford University Press).

Quigley, M., \& Ayihongbe, S. (2018) Everyday Cyborgs: on Integrated Persons and Integrated Goods, Medical Law Review, 26(2), pp. 276-308.

Moravec, H. (1988) Mind Children: The Future of Robot and Human Intelligence (Cambridge, London: Harvard University Press).

Solaiman, S. M. (2017) Legal personality of robots, corporations, idols and chimpanzees: a quest for legitimacy, Artificial. Intelligence and Law, 25(2), pp. 155-179, doi: https://doi.org/10.1007/s10506-016-9192-3.

Tegmark, M. (2017) Life 3.0 - Being Human in the Age of Artificial Intelligence (New York: Alfred A Knopf).

Vanderelst, D. \& Winfield, A. (2018) The Dark Side of Ethical Robots, AAAI/ACM Conference on AI, Ethics, and Society, February 1-3, 2018, retrieved from: http://www.aiesconference.com/wp-content/papers/main/AIES_2018_paper_98.pdf (January 3, 2019)

Van Est, R., Gerritsen, J. B. A., \& Kool, L. (2017) Human rights in the robot age: Challenges arising from the use of robotics, artificial intelligence, and virtual and augmented reality - Expert report written for the Committee on Culture, Science, Education and Media of the Parliamentary Assembly of the Council of Europe (PACE) (Rathenau Institute), retrieved from: https://www.rathenau.nl/sites/default/files/201802/Human\%20Rights\%20in\%20the\%20Robot\%20Age-Rathenau\%20Instituut2017.pdf (January 5, 2019)

Wiener, N. (1989) The human use of human beings: cybernetics and society, 3rd Edition (London: Free Association Books).

Zupanič, M. (2018) Italijanski deklici slovenska kirurga povrnila sluh. Delo, November 17, 2018, (Ljubljana: Delo d. o. o), retrieved from: https://www.delo.si/novice/svet/italijanski-deklici-slovenska-kirurga-povrnila-sluh110858.html (January 13, 2019). 